\title{
ALTERNATIF PERAWAT DALAM MENGAMBIL KEPUTUSAN
}

\author{
Khairun Nisa
}

\author{
Email : K.khairunnisa1311@gmail.com
}

\begin{abstract}
ABSTRAK
Pengambilan keputusan merupakan tindakan memilih salah satu solusi dari banyaknya alternatif-alternatif yang telah dikumpulkan. Dalam mengambil keputusan ada banyak pertimbangan yang harus di pertimbangkan, perawat juga harus memiliki pengetahuan terkait keputusannya tersebut. Perawat harus berfikir secara intelektual. ada 9 tahap yang dilalui individu dalam mengambil keputusan yaitu: Observasi. Mengenali masalah. Menetapkan tujuan. Memahami masalah. Menentukan Pilihan pilihan. Mengevaluasi Pilihan pilihan. Memilih. Menerapkan. Memonitor. Dalam menjalankan tugasnya. Perawat harus bertindak sesuai dengan kiat dan kemampuannya. Perawat harus tahu apa yang harus dia lakukan, apa yang boleh dan apa yang tidak boleh di lakukan
\end{abstract}

Kata Kunci : Perawat, Pengambilan keputusan, prinsip-prinsip etik. Tahap-tahap dalam mengambil keputusan.

\begin{abstract}
Decision making is the act of choosing one solution from the many alternatives that have been collected. In making decisions, there are many considerations that must be considered, nurses must also have knowledge related to these decisions. Nurses must think intellectually. There are 9 stages that individuals go through in making decisions, namely: Observation. Identifying problems. Setting goals. Understand the problem. Make a selection options. Evaluating options options. Choose. Apply. Monitor. In carrying out their duties. The nurse must act according to her means and abilities. The nurse must know what to do, what to do and what not to do
\end{abstract}

Keywords: Nurse, decision making, ethical principles. The stages in making a decision.

\section{LATAR BELAKANG}

Perawat merupakan profesi yang berperan besar dalam memberi pelayannan di rumah sakit. tugas perawat di rumah sakit bukan hanya untuk memberi asuhan keperawatan saja, masih banyak lagi hal yang perlu ia lakukan contohnya seperti menentukan tindakan keperawatan dan mengambil keputusan sesuai dengan kondisi pasiennya. Keputusan di definisikan sebagai hasil pemecahan masalah yang harus dihadapi dengan tegas. pengambilan keputusan merupakan pemilihan yang didasarkan oleh 2 alternatif atau lebih. Mengambil keputusan merupakan tindakan 
yang butuh konsentrasi dan pertimbangan yang besar, keputusan yang di ambil mampu memberikan resiko dan keuntungan juga. Terlebih bagi seorang perawat, segala tindakan dan keputusan yang ia ambil sangat berpengaruh pada keselamatan pasiennya, jika perawat salah dalam mengambil keputusan maka imbasnya yaitu pasien bisa semakin parah, dan yang lebih di takutkan yaitu pasien meninggal akibat tindakan yang kita lakukan itu salah.

Pengambilan keputusan merupakan tindakan memilih salah satu solusi dari banyaknya alternatif-alternatif yang telah dikumpulkan, diharapkan alternatif tersebut merupakan alternatif terbaik yang mampu memecahkan masalah yang sedang di hadapi. Dalam mengambil keputusan ada banyak pertimbangan yang harus di pertimbangkan, perawat juga harus memiliki pengetahuan terkait keputusannya tersebut. Perawat harus berfikir secara intelektual. Karena Pengetahuan perawat sangat penting dalam menentukan keputusan dan asuhan. Dalam menjalankan tugasnya. Perawat harus bertindak sesuai dengan kiat dan kemampuannya. Perawat harus tahu apa yang harus dia lakukan, apa yang boleh dan apa yang tidak boleh di lakukan. Semua hal yang di lakukan harus berdasarkan profesi dan SOP yang telah disediakan, semua ini bertujuan supaya perawat terhindar dari sanksi hukum.
Apabila perawat mekakukan hal gang bukan wewenangnya dan pasien mengalami kerugian atau bahaya maka peraway berhak mendapatkan hukum sesuai dengan undang-undang yang berlaku. Oleh karena itu untuk menghindari hal-hal yang tidak diinginkan maka perawat harus bertindak sesuai dengan wewenang dan kemampuannya.

\section{Kemampuan}

perawat mengidentifikasi masalah klien dan memilih solusi intervensi yang tepat tidak lepas dari kemampuan perawat berfikir kritis untuk mengali berbagai alasan berdasarkan evidence base dari setiap problem dan solusi yang teridentifikasi (Potter\& Perry, 2010). Untuk berfikir cerdas maka perawat harus bisa berfikir kritis dalam menghadapi setiap masalah dan pengalaman baru yang menyangkut pasien. dengan memiliki karakteristik percaya diri, berfikir mendalam, keadilan, tanggung jawab dan akuntabilitas, mengambil resiko, disiplin, kegigihan, kreatif, rasa ingin tahu, integritas dan randah hati, dimana karakteristik tersebut dapat dilihat dari sikap dalam memberikan asuhan keperawatan dari keterlibatan, kedewasaan untuk mengontrol emosi dan inovasi (Deswani, 2009).Berfikir kritis merupakan hal yang sangat penting dan tak terpisahkan dari asuhan keperawatan yang dilakukan oleh perawat. Berfikir kritis 
penting dilakukan sebelum mengambil keputusan dalam asuhan keperawatan karena berfikir kritis dalam keperawatan merupakan keterampilan berfikir perawat untuk menguji berbagai alasan secara rasional sebelum mengambil keputusan dalam asuhan keperawatan. Dengan

\section{METODE PENELITIAN}

Penulisan ini menggunakan metode literatur review dengan pendekatan jurnal, jurnal yang di gunakan adalah jurnal yang akurat yang mana di dalamnya memuat informasi yang di butuhkan penulis dalam

\section{HASIL}

Dari penelitian ini hasil pembahasan yang bia di ambil yaitu dalam mengambil keputusan perawat harus memiliki kemampuan yang baik, dan berfikir kritis. Dalam mengambil keputusan ada banyak yang harus di pertimnangkan mulai dari manfaat sampai dengan resiko yang mungkin terjadi. Tindakan pengambilan keputusan merupakan tindakan yang mengharuskan perawat untuk memilih satu dari beberapa pilihan. Untuk membantu perawat dalam menentukan keputusan maka perlu beberapa teknik dan prinsip. menentukan keputusan yang baik, dan memberikan asuhan yang benar, maka perawat akan mendapatkan kepercayaan dan dihargai oleh orang lain. Angka kepuasan pasien dapat di lihat dari gambaran kualitas layanan yang diberikan rumah sakit kepada pasiennya.

melakukan penelitian dan membantu dalam pembuatan pembuatan jurnal ini, informasi yang di butuhkan yaitu tentang Alternatif Perawat Dalam Mengambil Keputusan.

Dalam mengambil keputusan perawat juga harus melihat pada prinsip keperawatan. perawat harus berusaha mengambil keputusan yang terbaik.

Menurut Manulang (1994) ada lima tahap dalam mengambil keputusan yaitu :

\section{Tahap 1 menerima tantangan.}

Pengambilan keputusan dimulai sejak seseorang dihadapkan pada suatu masalah dan berani menyesaikannya. 
Tahap 2 mencari alternatif.

Untuk mengambil keputusan, maka sebelumnya kita harus menentukan beberapa alternatif yang mungkin bisa menyelesaikan permasalahan tersebutdan mempertimbangkan nilai-nilai dan tujuan dari alternatif tersebut..

\section{Tahap 3 penilaian alternatif.}

Menganalisis dengan cermat apa yang menjadi kekurangan dan kelebihan dari alternatif yang telah di pilih sebelumnya. Dan berusaha mencari informasi yang akurat dan mencari fakta-fakta yang bisa membantu kita dalam memilih alternatif yang sesuai.

\section{Tahap 4 menjadi terikat.}

\section{PEMBAHASAN}

Dalam mengambil keputusan ada banyak hal yang hafus dipertimbangkan mulai dari resiko, manfaat, strategi, serta tujuannya. Dalam menentukan keputusan diharapkan perawat mampu memberikan solusi yang terbaik dan menghindari resiko yang bisa membahayakan perawat dan juga pasien. Untuk memudahkan dalam mempertimbangkan keputusannya perawat bisa menggunakan prinsip-prinsip
Pada tahap ini, kita harus mampu memilih satu dari banyaknya alternatif. Keputusan pada tahap ini merupakan keputusan akhir yang kemudian akan dilanjutkan dengan memikirkan cara pelaksanaan dan membuat rencana cadangan.

\section{Tahap 5 berpegang pada keputusan.}

Setiap pengambilan keputusan maka yang di harapkan yaitu segalanya berjalan dengan lancar sesui perencanaan. tetapi hambatan sering terjadi. Memilih alternatif terbaik belumlah mencukupi. Jika keputusan tidak dilaksanakan secara memadai, hasil yang menggembirakan tidak akan tercapai.

keperawatan dan menyesuaikan dengan kadus yang sedang ja alami. Misalnya pada pasien yang sedang dalam keadaan koma, dan sudah tidak ada harapan hidup, maka perawat harus mampu memberikan pemahaman kepada keluarga pasien dan membantu jeluarga untuk memutuskan keputusan yang terbaik. Berikut ini ada beberapa prinsip keperawatan yang harus selalu di ingat dalam mengambil keputusan. Prinsip ini bisa digunakan oleh perawat dalam upaya menentukan keputusan yang 
tepat untuk pasiennya. Prinsip-prinsip tersebut antara lain, yaitu:

\section{Autonomy (Kemandirian)}

Perawat haruslah mampu berpikir logis dan cepat dalam mengambil keputusan.dan tetapenghormati dan menghargai pasiennya.

\section{Beneficence (Berbuat Baik)}

Berbuat baik terhadap pasien juga haruslah berlandaskan kepada ilmu dan kiat keperawatan.

\section{Justice (Keadilan)}

Sebagai perawat makan keputusan dan memberi asuhan yang di berikan harus secara adil sesuai dengan kebutuhan pasien tanpa ada perbedaan derajat dan sosial.

\section{Non-Maleficence (Tidak Merugikan)}

Keputusan dan tindakan yang di jalani harus di sesuaikan dengan kiat dan kemampuan perawat, agar tidak terjadi halhal yang merugikan dan mebhabayakan pasien

\section{Veracity (Kejujuran)}

Dalam hal ini perawat harus mampu memberikan informasi dan menjelaskan kondiai yang sebenarnya dengan

menggunakan komunikasi teurapeutik yang benar

\section{Fidelity (Menepati Janji)}

Dalam mebgjadapi pasien perawat harus mampu menepagi janji dan kontrak antara pasiwn dan perawat. Misalnya tentang perencanaan pengobatan yang akan dilakukan.

7. Confidentiality (Kerahasiaan) seorang perawat harus mampu menjaga rahasia atau privasi pasien, agar pasien terhindar dari ketidaknyamanan.

\section{Accountability (Akuntabilitas)}

8 prinsip di atas bisa di gunakan perawat untuk menentukan keputusan yang tepat. Ada banyak resiko yang bisa saja terjadi apabila perawat salah dalam mengambil keputusan, contohnya seperti kematian, kecelakaan, kurangnya kepercayaan. Dan Turunnya citra di masyarakat. Untuk menentukan keputusan perawat harus mebdiskusikan kepada pasien dan keluarga pasien. Dan menjelaskan tujuan dan manfaat yang akan di lakukan, apabila pasien fidak setunu dengan keputusan yang telah di buat contoh : pasien harus mendapatkan injeksi, namun pasien gidak bersedia. Maka si pasien dan keluarga harus menandatangani kontrak bahwa pasien tidak bersedia menerima terapi. Dengan pasien tersebut menandatangani kontrak tersebut berrti perawat sudah menjalankan kewajibannya 
sebagai perawat dan apabila terjadi kesalahan atau hal-hal yang membahayakan pasien sudah bukan menjadi ta ggung jawab perawat lagi.

Hubungan antar perawat ke pasien bisa menimbulkan aspek hukum, aspek hukum bisa berupa aspek hukum perdata, administrasi, maupun pidana. Pada hukum perdata bisa menimbulkan gugatan perdata. Tanggunggugat perdata dapat terjadi akibat melanggar aturan hukum, tidak mampu memprestasikan dan kealpaan (negligence) ataupun kecerobohan (recklessness) Tindakan ini bisa berakibat kematian/kecacatan tubuh

Cooke \& Slack (1991) menyatakan bahwa ada 9 tahap yang dilalui individu dalammengambil keputusan yaitu:

\section{a. Observasi.}

Individu memperhatikan bahwa ada sesuatu yang keliru atau kurang sesuai, sesuatu yang merupa kan kesempatan untuk memutuskan sedang terjadi padalingkungannya. Suatu kesadaran bahwa keputusan sedang diperlukan. Kesadaran ini diikuti oleh satu periode perenungan seperti proses inkubasi.

\section{b. Mengenali masalah.}

Sesudah mele wati masa -perenungan, atau karena akumulasi dari banyaknya bukti bukti atau tanda tanda - yang tertang kap, maka individu semakin -menyadari bahwa kebutuhan untukmemutuskan sesuatu menjadi semakinnyata.

\section{c. Menetapkan tujuan.}

Fase ini adalah masa mempertimbangkan harapan yang akandicapai dalam mengambil keputusan. Tujuan pada umumnya berkaitan dengan kesenjangan antara sesuatu yang telah diobservasi dengan sesuatu yang diharapkan, berkaitan dengan permasalahan yang dihadapi.

\section{d. Memahami masalah.}

Merupakan suatu kebutuhan bagi individu untuk memahami secara benar permasalah an, yaitu mendiagnosa akar - permasa lahan yang terjadi. Kesalahan -dalam mendiagnosa dapat terjadi karena memformulasikan masalah secara salah, karena hal ini akan mempe ngaruhi rangkaian proses selanjut nya. Jawaban yang benar terhadap pemahaman masalah yang salah memiliki makna/akibat sama seperti halnya jawaban yang salah terhadap pemahaman masalah yang benar. Jika batas batas keputusan telah didefinisikan dengan lebih sempit maka pilihan pilihan dengan sendirinya lebih mudah tersedia. Namun, jika keputusan yang diambil masih didefinisikan secara luas maka proses menetapkan pilihan merupakan proses kreatif.

\section{f. Mengevaluasi Pilihan pilihan.}


Fase ini melibatkan penentuan yang lebih luas mengenai ketepatan masing-masing pilihan terhadap tujuan pengambilan keputusan.

\section{g. Memilih.}

Pada fase ini salah satu dari beberapa pilihan keputusan yang tersedia telah dipilih, dengan pertimbangan apabila diterapkan akan menjanjikan suatu kepuasan.

\section{h. Menerapkan.}

Fase ini melibatkan perubahan- perubahan yang terjadi karena pilihan yang telah dipilih. Efektivitas penerapan ini bergantung pada ketrampilan dan kemampuan individu dalam menjalankan tugas serta sejauh mana kesesuaian pilihan tersebut dalam penerapan.

\section{i. Memonitor.}

Setelah

diterapkan,

maka

keputusantersebut sebaiknya dimonitor untuk melihat efektivitas dalam memecahkan masalah atau mengurangi permasalahan yang sesungguhnya. Penutup Pengambilan keputusan merupakan unsur penting dalam keperawatan karenaberhubungan dengan asuhan keperawatan yang akan diberikan kepada pasien. Perawat memiliki tanggung jawab dan kewenangan untuk mengambil langkah - langkah keperawatan yang diperlukan sesuai dengan standar keperawatan dalam pengambilan keputusan khususnya. Sedangkan untuk tahap - tahap pengambilan keputusan antaralain : observasi, mengenali masalh,menetapkan tujuan, memahami masalah, menentukan pilihan, evaluasi pilihan, memilih, menerapkan, dan memonitori.

\section{Menurut Manulang (1994) ada lima tahap dalam mengambil keputusan yaitu :}

\section{Tahap 1 menerima tantangan.}

Pengambilan keputusan dimulai sejak seseorang dihadapkan pada suatu masalah dan berani menyesaikannya.

\section{Tahap 2 mencari alternatif.}

Untuk mengambil keputusan, maka sebelumnya kita harus menentukan beberapa alternatif yang mungkin bisa menyelesaikan permasalahan tersebutdan mempertimbangkan nilai-nilai dan tujuan dari alternatif tersebut.

\section{Tahap 3 penilaian alternatif.}

Menganalisis dengan cermat apa yang menjadi kekurangan dan kelebihan dari alternatif yang telah di pilih sebelumnya. Dan berusaha mencari informasi yang akurat dan mencari fakta-fakta yang bisa 
membantu kita dalam memilih alternatif yang sesuai.

\section{Tahap 4 menjadi terikat.}

Pada tahap ini, kita harus mampu memilih satu dari banyaknya alternatif. Keputusan pada tahap ini merupakan keputusan akhir yang kemudian akan dilanjutkan dengan memikirkan cara pelaksanaan dan membuat rencana cadangan.

Tahap 5 berpegang pada keputusan.

\section{PENUTUP}

Untuk menentukan dan mengambil keputusan perawat perlu mengikuti pelatihan, Pelatihan memiliki manfaat, yaitu berupa tanggung jawab dan prestasi yang mampu memudahkan perawat, serta meningkatnya pengetahuan, keterampilan, sikap serta membantu perawat menghilangkan rasa takut ketika dihadapkan dengan hal-hal baru. Manfaat yang didapat dari pelatihan yaitu bisa terbentuknya sikap lebih positif terhadap orientasi yang akan dicapai organisasi dan sikap moral yang lebih baik. Dengan melakukan latihan dan membiasakan diri dengan masalah maka perawat akan lebih berpengalaman dan mampu menentukan keputusannya tanpa ragu. Dalam menentukan keputusan perawat juga harus memposisikan diri sebagaimana
Setiap pengambilan keputusan maka yang di harapkan yaitu segalanya berjalan dengan lancar sesui perencanaan. tetapi hambatan sering terjadi. Memilih alternatif terbaik belumlah mencukupi. Jika keputusan tidak dilaksanakan secara memadai, hasil yang menggembirakan tidak akan tercapai.

semestinya. Untuk menghindari hal yang yang tidak diinginkan maka segala tindakan yang dilakukan harus berdasarkan wewenang dan selalu menerapkan SOP yang berlaku. Dalam menentukan keputusan perawat harus meertimbangkan keadaan pasien. 


\section{REFERENSI}

Deniati, K., Anugrahwati, r., \& suminarti, t. (2018). Pengaruh Berfikir Kritis Terhadap Kemampuan Perawat Pelaksana dalam Melakukan Asuhan Keperawatan di Rumah Sakit Hermina Bekasi Tahun 2016. Holistik Jurnal Kesehatan, 12(1), 21-25.

Erawantini, F. \& Wibowo, N. S. 2019. Implementasi Rekam Medis Elektronik dengan Sistem Pendukung Keputudsan Klinis. Jurnal Teknologi dan Terapan. 6(2): 75-78.

Fadhillah, nurul,. Noraliyatun jannah. (2017). Pelaksanaan Prinsip Etik Keperawatan dalam Asuhan Keperawatan Pada Perawat Pelaksana. Jurnal ilmiah Mahasiswa fakultas keperawatan, 2(3), 1-7.

Feriadi, afton. P.,ery.novyriana,p. (2020).

Gambaran Tingkat Penerapan

Prinsip Etik Keperawatan di Ruang Rawat Inap Kelas III Rumah Sakit PKU Muhammadiyah

Gombong.Jurnal Ilmiah Kesehatan Keperawatan. 16(1):19-27.

Khairina,Ilfa. M.,Hema. Huriani, E. (2018). Faktor-Faktor Yang Berhubungan Dengan Pengambilan
Keputusan Perawat Dalam Ketepatan Triase di Kota Padang. journal.umpo.ac.id/index.php/ijhs. 2(1):1-11.

Nurhayati. (2016). Analisis Hubungan Perilaku Caring Dengan Kinerja Perawat Pelaksana Menerapkan Prinsip Etik Keperawatan Dalam Asuhan Keperawatan Di Rumah Sakit Bhayangkara Mapaa Oudang Makassar, Jurnal Kesehatan, 217223.

Pangaribuan,Resmi.(2016). Persepsi Perawat Terhadap Prinsip-Prinsip Etik dalam Pelaksanaan Tindakan Keperawatan di ICU Rumah Sakit TK. Ii Putri Hijau Medan Nurse Perceptions Of Principles Of Conduct In The Implementation.Jurnal Riset Hesti Medan.1(1):37-44.

Simamora, R., H. (2005). Hubungan Persepsi Perawat Pelaksana Terhadap Penerapan Fungsi Pengorganisasian Yang Dilakukan Oleh Kepala Ruangan Dengan Kinerjanya Diruang Rawat Inap RSUD Kot Jakarta Utara (doctoral dissertation, Tesis fik ui, tidak dipublikasikan). 
Simamora, R., H. (2019). Menjadi perawat Yang: cih'huy. Surakarta: kekata

Publisher. Sumijatun. (2009).

Konsep dasar dan Aplikasi

pengambilan keputusan klinis.

Jakarta: trans info media jakarta.

Sumijatun. (2009). Manajemen

Keperawatan. Konsep Dasar

Aplikasi Pengambilan Keputusan

Klinis. Jakarta: Trans info media.

Touwe, F. R., dkk. 2019. Pemanfatan Rekam Medis Sebagai Sumber Informasi Untuk Pengambilan Keputusan di Ruang Rawat Inap RSI Faisal Makassar. Jurnal Mitrasehat. 9(2): 540-551.

Yulia, s., hamid, a. Y. S., \& mustikasari, m.

(2012).

Peningkatan

Pemahaman Perawat Pelaksana

Dalam Penerapan Keselamatan

Pasien Melalui

Pelatihan Keselamatan Pasien.

Jurnal keperawatan indonesia, 15(3), 185-192. 
